\title{
Efektivitas Pembelajaran Jarak Jauh dengan Memanfaatkan Teknologi pada Masa Pandemi Covid-19 di Indonesia
}

\author{
Farida Repelitawaty Kembaren ${ }^{1 *}$, Wika Lutfiah Sakinah², Haviza Septiannur ${ }^{3}$, \\ Jihan Karina Putri ${ }^{4}$ \\ 1,2,3,4 Universitas Islam Negeri Sumatera Utara Medan, Indonesia \\ * Corresponding Author. E-mail: ${ }^{1}$ faridarepelitawatykembaren@uinsu.ac.id
}

Receive: $17 / 02 / 2021$

Accepted: 22/02/2021

Published: 01/03/2021

\begin{abstract}
Abstrak
Di Indonesia pandemi covid 19 ini mengakibatkan lumpuhnya aktivitas masyarakat baik dari sisi ekonomi,sosial bahkan hingga pendidikan. Pada sisi pendidikan pemerintah menerapkan kebijakan untuk belajar secara online, dimana para siswa dan guru tidak bertemu tatap muka secara langsung. Disini guru dan siswa memanfaatkan teknologi yang dapat di gunakan untuk mendukung kegiatan belajar mengajar di masa pandemi. Maka dari itu penelitian ini bertujuan untuk meninjau lebih dalam bagaimana efektivitas pembelajaran jarak jauh menggunakan smartphone di Indonesia, kami melakukan survei di Kota Langsa, Aceh, Indonesia. Dengan menggunakan metode penelitian kualitatif, kita dapat mengetahui bahwa pada dasarnya belajar jarak jauh dengan menggunakan teknologi tidak terlalu efektif serta menyebabkan banyak kesulitan dari berbagai pihak. Dari hasil penelitian diharapkan seluruh tenaga pengajar untuk mengetahui dan menyadari bahwasanya siswa membutuhkan penjelasan materi lebih lanjut agar siswa dapat memahami materi-materi pembelajaran sehingga belajar jarak jauh secara online sama efektifnya dengan belajar tatap muka secara langsung.
\end{abstract}

Kata Kunci: Belajar online, Covid-19, Efektifitas, Siswa Indonesia,Teknologi.

\section{The Effectiveness of Distance Learning by Utilizing Technology during the Covid-19 Pandemic in Indonesia}

\begin{abstract}
In Indonesia, the COVID-19 pandemic has resulted in the paralysis of community activities both in terms of economic, social and even education. On the education side, the government implements a policy for online learning, where students and teachers do not meet face-to-face. Here teachers and students take advantage of technology that can be used to support teaching and learning activities during the pandemic. Therefore this study aims to review more deeply how the effectiveness of distance learning using smartphones in Indonesia, we conducted a survey in Langsa City, Aceh, Indonesia. By using qualitative research methods, we can find out that basically distance learning using technology is not very effective and causes many difficulties from various parties. From the results of the study, it is expected that all teaching staff will know and realize that students need further explanation of the material so that students can understand the learning materials so that online distance learning is as effective as face-to-face learning.
\end{abstract}

Keywords: Online Learning, Covid-19, Effectiveness, Indonesian Students, Technology. 
peraturan yang telah dirancang dan diterapkan oleh pemerintah kepada masyarakat sejak awal terjadinya masamasa kritis ini hingga sekarang. Aktivitas seluruh warga dunia banyak yang terkendala, bahkan tertunda karena pembatasan ruang gerak tersebut. Mulai dari bidang ekonomi, pendidikan, pariwisata, keagamaan, dan masih banyak lagi aspek kegiatan masyarakat yang terpaksa dihentikan atau diminimalkan karena keadaan ini.

Khususnya di Indonesia, berbagai kebijakan dari pemerintah telah dirancang sedemikian rupa untuk segera menghentikan penyebaran virus yang berkembang dengan sangat cepat dan melakukan berbagai macam cara agar pandemi covid-19 segera berakhir.

Mulai dari anjuran social distancing (menjaga jarak) sampai physical distancing (pembatasan kontak fisik) telah dilakukan sampai saat ini. Di tambah beberapa waktu terakhir, pemerintah membuat banyak program yang sejalan dengan anjuran pembatasan ruang aktivitas masyarakat seperti; PSBB, PSBB Transisi, PPKM Darurat, hingga kini Indonesia sedang menerapkan kebijakan PPKM level 4.

Pembatasan ruang aktivitas ini benar-benar membuat masyarakat harus beradaptasi dengan hal-hal baru. Keadaan seperti ini memaksa seluruh aspek kegiatan dilakukan dengan daring sebagai salah satu langkah pencegahan penyebaran virus covid-19. Contohnya dalam bidang pendidikan, di mana pembelajaran dilakukan dari rumah secara online antara tenaga pendidik dan anak didiknya. Pembelajaran online seperti ini menggunakan media komunikasi virtual dengan memanfaatkan beragam aplikasi yang dapat diunduh dengan mudah di berbagai macam perangkat.

Dalam hal ini, tenaga pendidik dituntut aktif, komunikatif, dan kreatif serta paham akan dunia digital demi proses pembelajaran yang dilaksanakan berjalan dengan baik dan tidak membosankan. Serta, setiap anak didik juga diharuskan mempunyai dan mengerti cara pemakaian perangkat yang digunakan, hadir dengan keadaan yang baik, serta aktif walau kegiatan pembelajaran dialihkan dalam pertemuan online. Agar proses pembelajaran terlaksana dengan sempurna dan mendapatkan feedback seperti yang diharapkan oleh kedua belah pihak.

Proses pembelajaran online atau via daring (dalam jaringan) seperti ini mewajibkan semua pihak memiliki gawai dan benar-benar memahami bagaimana cara pemakaiannya yang benar. Dengan terjalannya komunikasi serta tersedianya perangkat yang mendukung, membuat aktivitas belajar secara daring dapat dilakukan dengan baik dan tetap terlaksana sesuai dengan kurikulum yang sudah ditetapkan.

Pemerintah juga telah menetapkan secara formal, pembelajaran jarak jauh atau yang disingkat dengan PJJ tercantum dalam Surat Edaran Kemendikbud Nomor 4 Tahun 2020 tentang Pelaksanaan Pendidikan dalam Masa Darurat Covid-19, yang kemudian ditindaklanjuti sesuai dengan Surat Edaran Nomor 15 Tahun 2020 tentang Pedoman Penyelenggaraan Belajar dari Rumah dalam Masa Darurat Penyebaran Covid-19. Isi dari Surat Edaran Nomor 15 Tahun 2020 mengenai proses pembelajaran. Di mana proses pembelajaran tersebut dapat berlangsung dari rumah melalui pembelajaran jarak jauh secara daring/luring selama darurat penyebaran covid-19.

Namun, di balik kemudahan yang disajikan dalam adaptasi proses pembelajaran virtual seperti ini, tentu ada beberapa tenaga pendidik dan anak didik yang mengalami berbagai macam keterbatasan. Seperti contohnya, banyak siswa di sekolah yang merasa sulit memahami materi yang diberikan oleh guru mereka karena sudah terbiasa mendapatkan materi pembelajaran yang diterangkan secara langsung. Juga, karena dilakukan di rumah masing-masing, mereka kehilangan kesempatan untuk berdiskusi mengenai topik materi yang didapatkan sehingga 
merasa sedikit kewalahan akan tugas-tugas yang diberikan oleh guru.

Selain itu, guru-guru di sekolah pun mempunyai sedikit keresahan mengenai cara bagaimana agar bisa melakukan proses mengajar yang baik dan tidak membuat para siswa menjadi bosan serta bisa memahami materi yang diberikan dengan lancar. Juga, banyak orangtua siswa yang mengeluh tentang keadaan mereka yang juga merasa sulit untuk membantu proses pembelajaran anak-anak di rumah karena kurangnya fasilitas pendidikan yang mendukung di rumah mereka. Di tambah, bagi para siswa dan guru yang berada bukan di wilayah kota, mereka mempunyai keterbatasan perangkat serta sinyal yang mendukung proses pembelajaran secara daring ini.

Untuk itu, dengan segala permasalahan yang terjadi dalam bidang pendidikan di masa-masa covid-19 seperti ini, perlu adanya penelitian lebih lanjut agar kendala yang ada dapat diuraikan secara jelas dan tersusun. Sehingga dapat dilakukan pendalaman masalah melalui berbagai macam teori pendukung serta pembahasan hasil dari penelitian yang dilakukan secara langsung kepada objek terkait agar dapat mengetahui bagaimana sesungguhnya perkembangan aspek pendidikan di era pandemi dan mencari solusi untuk setiap masalah yang terjadi. Adapun beberapa alasan utama peneliti memilih masalah ini:

1. Peneliti terlibat langsung dalam proses pembelajaran daring dan pernah merasakan kendala-kendala yang sama seperti yang dikeluhkan oleh siswa di sekolah.

2. Sejauh ini, walau sudah ada beberapa yang meneliti terkait dengan masalah ini, peneliti merasa bahwa di setiap daerah pasti ada kebijakan dan keadaan yang berbeda dalam menyikapi masalah-masalah dalam proses pembelajaran daring.

3. Hasil penelitian akan memberikan manfaat yang bisa diaplikasikan oleh peneliti sendiri dan para tenaga pendidik serta anak didiknya dalam usaha beradaptasi dengan media pembelajaran virtual yang baik dan tepat sasaran.

\section{Metode}

Metode penelitian yang digunakan dalam studi kasus ini ialah metode penelitian kualitatif, yaitu dalam prosedur penelitian menghasilkan data deskriptif berupa perilaku yang dapat diamati untuk mendapatkan evaluasi siswa dari pengalaman mereka dengan pemanfaatan teknologi di masa pandemic covid 19 sebagai media pembelajaran. Penelitian kualitatif diambil dari jenis studi kasus model penelitian yang membahas mengenai individu. Dalam subjek penelitian ialah melakukan kuisioner dan membuat beberapa pertanyaan terkait dengan pembahasan, yaitu pembelajaran daring (dalam jaringan) menggunakan teknologi dan menyebarluaskan link google form kepada siswa/i di Kota Langsa, dan mendapatkan sampel sebanyak 50 responden yang berasal dari siswa SD, SMP, dan SMA.

\section{Hasil dan Pembahasan}

Kami telah melakukan survey dengan menggunakan teknologi, yaitu dengan menyebar link kuesioner dalam bentuk platform google form, yang kemudian jawaban yang diberikan oleh responden terdata secara otomatis dengan tampilan diagram. Adapun responden survey kami ditargetkan kepada siswa/i yang berada di bangku Sekolah Dasar hingga Sekolah Menengah atau Kejuruan. Hasil survey menunjukkan bahwa $42 \%$ dari 50 orang responden merupakan siswa/i yang berasal dari Sekolah Menengah Atas atau Kejuruan, $18 \%$ berasal dari Sekolah Menengah Pertama, dan $40 \%$ berasal dari sekolah dasar.

Kepemilikan dan Penggunaan Teknologi 
Selama pandemic covid 19, seluruh siswa diwajibkan memiliki perangkat teknologi yang dapat digunakan untuk mendukung kegiatan pembelajaran.

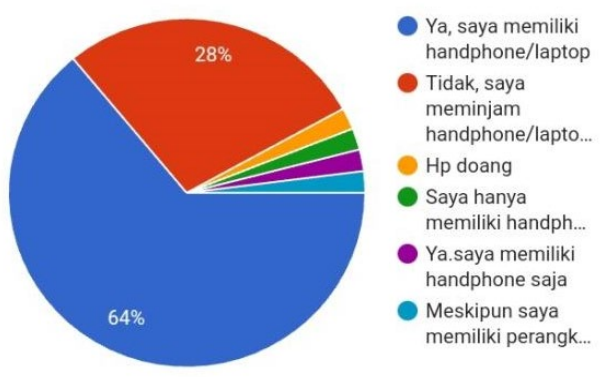

Gambar 1. Diagram persentase kepemilikan teknologi

Berdasarkan hasil survey, rata-rata siswa memiliki perangkat untuk mendukung belajar online, walaupun terdapat $28 \%$ siswa yang tidak memiliki handphone/laptop secara pribadi, mereka tetap berusaha bagaimana caranya agar mereka tetap bisa mengikuti proses belajar online. Berbagai aplikasi digunakan untuk mengikuti kelas online. Seluruh siswa diwajibkan untuk menggunakan teknologi baik handphone maupun laptop. Seluruh siswa juga dituntut untuk pintar dalam menggunakan aplikasi-aplikasi pendukung proses belajar mengajar. Berbagai aplikasi digunakan oleh siswa seperti whatsApp, Zoom, Google Meet, dan lainnya.

\section{Efektivitas Pembelajaran Jarak Jauh Menggunakan Teknologi}

Saat ini seluruh manusia dapat menggunakan teknologi terutama handphone, dan tidak terkecuali anak-anak usia sekolah. Dimasa pandemic saat ini para siswa tidak merasa kesulitan dalam menggunakan teknologi karena sudah terbiasanya menggunakan teknologi dalam kehidupan sehari-hari. Namun, untuk melakukan belajar jarak jauh dengan menggunakan teknologi handphone atau laptop dan sejenisnya, para siswa memiliki permasalahan dalam memahami pelajaran, sehingga hal ini menjadi pertimbangan bagi pemerintah setempat dan juga pihak sekolah untuk membuat kebijakan baru dengan tujuan agar para siswa dapat belajar dengan baik dan nyaman, yaitu dengan melakukan belajar tatap muka secara bergantian. Berdasarkan hasil survey, terdapat $90 \%$ siswa yang tetap belajar tatap muka walaupun hal itu dilakukan secara bergantian. Tetapi, $22 \%$ di antaranya tetap sekolah seperti biasa. Pemerintah dan pihak sekolah mempertimbangkan dari berbagai aspek, termasuk dampak yang dirasakan oleh siswa akibat belajar online ini.

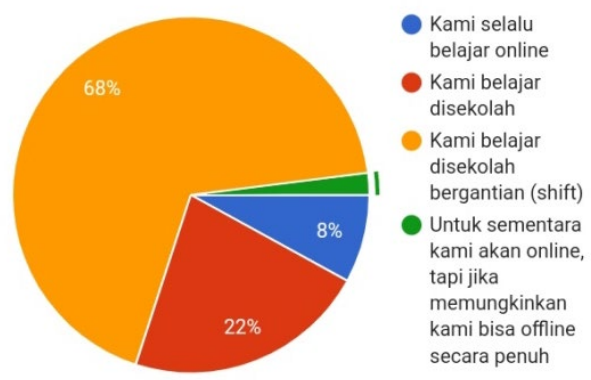

Gambar 2. Diagram persentase siswa yang sekolah tatap muka

Dengan melakukan belajar jarak jauh, tidak semua siswa memahami materi yang disampaikan oleh guru mereka dengan baik. Bahkan lebih dari 50\% responden menyatakan bahwa mereka tidak memahami materi jika belajar online. Dan hampir $60 \%$ siswa menyatakan bahwa mereka memahami materi saat mereka bertemu langsung oleh guru .
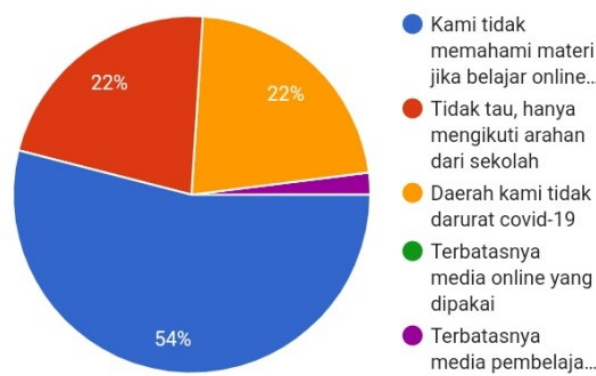

Gambar 3. Diagram persentase siswa tentang pemahaman materi saat belajar tatap muka di sekolah

Dengan melakukan pembelajaran jarak jauh ini siswa tidak terlalu bersemangat untuk belajar secara online. Untuk meningkatkan kualitas belajar, para guru biasanya mewajibkan para siswa untuk 
melakukan praktek agar siswa lebih memahami materi yang dijelaskan oleh guru. Namun, berdasarkan hasil survey $44 \%$ dari 50 siswa menyatakan bahwa mereka tidak dapat melakukan praktek jika tidak dapat bimbingan langsung dari guru. Sehingga dapat kita simpulkan bahwa para siswa sangat membutuhkan belajar secara tatap muka untuk lebih memahami materimateri yang diberikan.

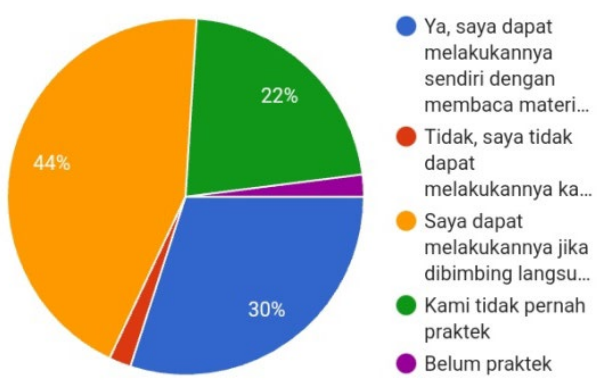

Gambar 4. Diagram persentase siswa terkait tugas praktek

Guru tetap memiliki tanggung jawab dan mencoba untuk memanfaatkan segalanya guna membuat belajar jarak jauh menggunakan teknologi menjadi lebih efektif. Namun, 48\% dari 50 siswa menyatakan bahwa mereka merasa kurang baik atau merasa kurang puas untuk berinteraksi dengan guru secara online. Hal ini disebabkan karena tidak adanya penjelasan dari materi yang diberikan. Sehingga siswa merasa bingung dengan materi dan tugas yang diberikan karena tidak adanya bimbingan.

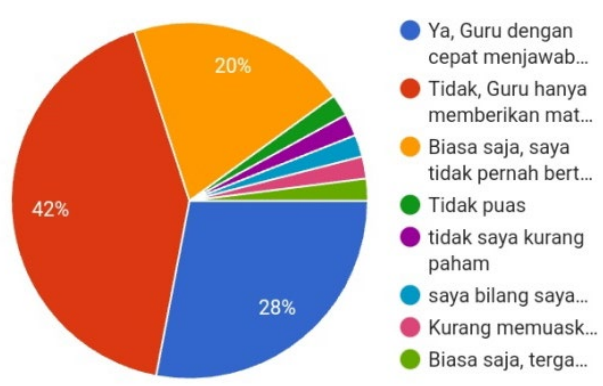

Gambar 5. Diagram persentase siswa terkait interaksi dengan guru secara online

Para siswa merasa tidak memiliki jiwa kompetisi yang tinggi karena tidak bertemu teman-teman secara langsung, dan juga tidak bersosialisasi langsung dengan guru, maupun teman-teman di sekolah. Belajar dari rumah juga dinilai kurang efektif karena mereka tidak bisa benar-benar fokus untuk memahami materi pembelajaran karena beberapa responden yang menyatakan lingkungan rumah tidak mendukung untuk belajar. Dan juga siswa kesusahan untuk belajar dirumah dikarenakan keterbatasan jaringan saat sekolah online.

Mengenai hal ini, sama seperti penelitian-penelitian sebelumnya bahwa sekolah secara online (jarak jauh/homeschooling) menuai pro dan kontra di kalangan siswa, guru, dan orang tua. Siswa biasanya memiliki permasalahan dalam pemahaman materi, keterbatasan perangkat teknologi, tidak lihai menggunakan teknologi, dan juga sering terjadinya kecurangan, sehingga siswa mendapatkan nilai yang mungkin tidak sesuai dengan kemampuannya (Adedoyin, dan Soykan, 2020), dan karena mengalami kesulitan dalam memahami materi, biasanya siswa yang memiliki prestasi belajar yang rendah semakin merasa tertekan karena banyaknya kesulitan yang dihadapi (Mælan,et.al., 2021). Para siswa mengalami kondisi mental yang kurang stabil karena sulitnya untuk bersosialisasi dan komunikasi, namun di beberapa penelitian menunjukkan salah satu sisi positifnya adalah kesempatan siswa yang berprilaku buruk kepada temannya telah hilang, sehingga siswa yang sering mengalami perundungan merasa lebih aman untuk belajar di rumah (Flynn, et.al., 2021). Meskipun demikian, di Indonesia sendiri para siswa tidak benar-benar putus dalam berkomunikasi dan bersosialisasi, siswasiswa di Indonesia tetap mengikuti alur dari kebijakan ini, walaupun mereka sedikit mengalami tekanan karena merasa hari-hari mereka terasa membosankan, mereka tetap diperbolehkan bertemu dan bermain dengan teman-teman tetapi tetap menjalankan protokol kesehatan.

\section{Simpulan}


Jurnal Edumaspul,5 1), Year 2021- 691

(Farida Repelitawaty Kembaren, Wika Lutfiah Sakinah, Haviza Septiannur, Jihan Karina Putri)

Pandemi Covid-19 merupakan suatu peristiwa yang tidak dapat kita hindari. Munculnya pandemic ini membuat dunia berjalan di luar ekspektasi. Dunia ekonomi dan pendidikan seketika berantakan karena banyaknya aturan-aturan yang harus dijalankan. Dalam pendidikan sendiri, para siswa hingga mahasiswa akhirnya merasakan belajar jarak jauh tanpa bertemu langsung oleh guru pembimbing dan juga teman-teman.

Banyak terjadi pro dan kontra terhadap kebijakan ini, saat ini para siswa menuntut untuk kembali belajar tatap muka di sekolah. Berbagai alasan dan faktor menjadi pertimbangan bagi pemerintah setempat untuk membuat kebijakan baru dalam menghadapi persoalan ini. Seluruh pihak terkait memiliki persoalan masingmasing, seperti guru yang harus terus menjaga

Komunikasi dengan para siswanya serta memikirkan bagaimana cara menghadapi siswa yang terkadang merasa bosan dan hampir seluruhnya sulit memahami materi, seperti dengan membangun komunikasi lebih terbuka kepada anak-anak ketika mereka tidak memahami suatu pelajaran, dan beri mereka kesempatan untuk bertanya, menjalin komunikasi dengan para orang tua siswa untuk membahas tentang perkembangan anak, pelajaran anak, dan masalah-masalah yang di hadapi oleh para siswa. Dan yang paling penting adalah melakukan refreshing atau penyegaran pikiran agar para siswa tidak merasa bosan dan juga merasa tertekan dengan kondisi yang di alaminya.

\section{Daftar Pustaka}

[1] Adedoyin, Olasile Babatunde \& Emrah Soykan. (2020). Covid-19 pandemic and online learning: the challenges and opportunity. Interactive Learning
Environments.

https://doi.org/10.1080/10494820.2020.1813 $\underline{180 .}$.

[2] Azhar, Arsyad. (2014). Media Pembelajaran: Istilah Pokok Seputar Media Pembelajaran, Jakarta: Rajawali Pers.

[3] Bambang, Warsita. (2008). Teknologi Pembelajaran. Jakarta: PT. Rineka Cipta.

[4] Flynn, Niamh. et.al. (2021). "Schooling at Home" in Ireland during Covid-19: Parents' and Students' Perspectives on Overall Impact, Continuity of Interest, and Impact on Learning. Irish Educational Studies, 40(2).

https://doi.org/10.1080/03323315.2021.1916 $\underline{558}$.

[5] Ikhwana, Dina Afriana. (2021). Strategi Pembelajaran Efektif Masa Pandemi Covid 19. Banten: Media Sains Indonesia.

[6] Maelan, Ellen Nesset. et.al. (2021). Norwegian students' experiences of homeschooling during the COVID-19 pandemic. European Journal of Special Needs Education, 36(1). https://doi.org/10.1080/08856257.2021.1872 $\underline{843}$.

[7] Nasution, S. (2010). Pendekatan dalam Proses Belajar dan Mengajar. Jakarta: PT. Bumi Aksara.

[8] Papouli, Eleni, et.al. (2020). The use of digital techonolgy at home during the COVID - 19 outbreak: Views of social work students in Greece. Social Work Education, 39(8).

https:// doi.org/10.1080/02615479.2020.1807496.

[9] Salsabila, Unik Hanifah. et.al. (2020). Peran Teknologi dalam Pembelajaran di Masa Pandemi Covid 19. Jurnal Penelitian dan Kajian Sosial Keagamaan, 17(2).

[10] Sudarwan, Danim. (2008). Media Komunikasi Pendidikan Pelayanan Professional Pembelajaran dan Mutu Hasil Belajar. Jakarta: Bumi Aksara. 